\title{
Ethical Perception of Tax Evasion in Indonesia: Determinants and Consequences on Voluntary Tax Compliance
}

\author{
Arfah Habib Saragih ${ }^{*}$, I Dewa Nyoman Suartama Putra ${ }^{2}$ \\ 1,2 Departemen Ilmu Administrasi Fiskal, Universitas Indonesia, Jalan Margonda Raya, \\ Kota Depok 16424, Indonesia \\ *Corresponding author; Email: ${ }^{*}$ arfah.habib11@ui.ac.id; ${ }^{2}$ i.dewa73@ui.ac.id
}

\begin{abstract}
This study investigates the factors of ethical perception of tax evasion. We also investigate the effect of ethical perception on tax compliance. Surveys are conducted with 291 participants consist of students, lecturers, professionals, and business owners from various backgrounds and majors in Indonesia. The data is then processed with the PLS-SEM method. Our analysis shows a negative and significant effect of idealism, tax knowledge toward the ethical perception of tax evasion, a positive and significant impact of relativism toward the ethics perception of tax evasion, and no significant effect of religiosity and educational level toward the ethics perception of tax evasion. We find that ethical perception is a significant predictor of voluntary tax compliance. Those findings can help tax authorities to increase voluntary tax compliance by shaping tax evasion perceptions and considering what factor affects them.
\end{abstract}

Keywords: Ethical perception; tax evasion; tax compliance; ethical philosophy; tax knowledge; education level; moral judgment.

\section{INTRODUCTION}

Tax evasion has been one of the contentious topics since the tax collection, especially regarding the ethical aspects of the practice that until now have not been agreed upon by experts [48]. [11] finds that the ethical aspects of tax evasion are formed from moral judgment or perception. Various empirical studies have been conducted to find various opinions on the perception of tax evasion from an ethical point of view. Research conducted in Haiti, India, and Estonia finds that there are a variety of reasons that justify tax evasion as an ethical act [44], [45], [46]. Research in Haiti finds that the strongest reason why respondents considered tax evasion ethical is a high tax rate [46], whereas in India the strongest reason is when most taxes are wasted free of charge [45]. A study in Estonia finds that the reasons justifying tax evasion are corrupt governance as well as human rights violations [44].

Those different perceptions about tax evasion are based on individual moral judgment. Moral judgment reflects an individual's ability to determine an ethical action. [35] in Moral Development Theory defines moral judgment as a form of judgment, an assessment of a value, a social judgment, and an assessment that helps individuals to act. That theory was developed by [54]. His model explains that moral judgment is the stage after moral recognition. After people decide what is right or wrong in moral judgment, then they attempting to perform the right behaviors (moral intentions) [56]. Moral judgment develops over time and is influenced by factors such as ethical philosophy, religiosity, education, and knowledge [4], [7], [25].

Ethical philosophy, also known as ethical ideology, is an individual's values, consisting of relativism and idealism, which are known to influence the moral judgment process [15]. [25] found that idealism and relativism have a noteworthy impact on moral judgment, particularly in a legally unethical situation. Studies in the context of tax evasion are very limited. Recent literature was conducted by [58] and finds that selfinterest tax avoidance is negatively related to idealism, while it is positively related to relativism.

Religiosity is also known to have an impact on an individual's moral judgment. In the context of ethical perception of tax evasion, [4] finds in Christian and Islamic groups, the frequency of attendance in religious activities has a significant connection to the perception of tax evasion. From a religious perspective, it is also suggested that tax evasion can be considered ethical or unethical. For example, studies conducted by [41] finds that Christian religious groups largely consider tax evasion to be unethical, some considered it always unethical, and ethical for some reason.

Another variable that influences the ethical perception of tax evasion is tax knowledge. Tax knowledge consists of three elements, namely legal knowledge related to understanding the rules of taxation; procedural knowledge which is the know- 
ledge of procedures in carrying out tax obligations; and general knowledge which is general knowledge and fiscal awareness [6]. [7] whose research focuses on general tax knowledge, finds that there is a negative influence between tax knowledge and perceptions of tax evasion.

Previous research has also found that individuals with different levels of education have different ethical perceptions of tax evasion. The higher the education, the more likely are individuals to oppose tax evasion [27]. However, other research conducted in 84 countries found that groups with low education are the most opposed groups to tax evasion. The middle class scored the lowest in opposing tax evasion, while the high group was among the two groups [42].

Kohlberg does not emphasize the relationship and consistency between moral development and moral behavior, but Kohlberg does explain that moral behavior is in line with or following the development of moral and moral judgment. [61] then researched to see how moral development affects tax compliance. The results find that moral development has a significant influence on tax compliance behavior.

Research in Indonesia on the influence of religiosity, education level, and tax knowledge on ethical perceptions of tax evasion and the influence on tax compliance is still limited. Some previous studies have focused on other factors. For example, [50] focusing on taxation systems, quality of tax services, and discrimination; while [13] using gender, religiosity, and love for money; and [37] focused on national culture. Looking at this limitation, this study aims to add a new perspective on how ethical perceptions of tax evasion in Indonesia and (a) analyze the influence of ethical philosophy on ethical perceptions of tax evasion [58], (b) analyze the influence of religiosity on ethical perceptions of tax evasion [4], [41], (c) analyze the influence of tax knowledge on ethical perceptions of tax evasion [27], [42], (d) analyze the influence of education levels on ethical perceptions of tax evasion [7], and (e) analyze the influence of ethical perception of tax evasion on tax compliance [61].

\section{Moral Judgment}

[35] states that an individual's moral judgment is an ongoing and lifelong process. Later, [54] explains that the development of moral or moral judgment at a new stage not only replaces the previous stage, not added to it, but rather the new stage is the transformation of the old element along with the new elements that make up the new structure.

[54] uses moral judgment terminology to define Kohlberg's Moral Development theory.
Moral development and moral judgment are used interchangeably in various literature. In this research, we use moral judgment to define Kohlberg's theory. [54] in neo-Kohlbergian view defines moral development or moral judgment as a psychological concept that describes the process of an individual determining an action, is it morally correct or wrong. Moral judgment also includes individual processes in defining moral issues, how to resolve conflicts between parties, and determining the foundation for deciding an action.

Before making any decisions, individual needs to consider all relevant information about the situations, especially moral information. Then, they apply their moral reasoning. Moral judgment processes sometimes are not conscious, some of them are rather automatic and habitual. Moral judgment reflects both individual's way of thinking, which is affected by their cognitive level, and their beliefs, states of mind, and values, which reflects an extension of a person and cultural impacts [54], [56].

\section{Ethical Philosophy and Ethical Perception of Tax Evasion}

An individual's response to a situation that has an ethical dilemma depends on differences in their respective moral philosophies [58]. [16] states that the ethics of idealism and the ethics of relativism represent two separate dimensions. Idealists care about the well-being of others and assume that this can happen with the right action. Relativists view the situation from a variety of perspectives in addition to universal moral principles. Relativists think that certain situations may require actions that deviate from actions that are considered universally correct.

Previous research has shown that there is a link between ethical ideology and ethical decisionmaking processes. [16] researched to see how ethical philosophy affects an individual's moral judgment. He finds absolutists (low relativism, high idealism) are judged to be crueler toward someone who performs actions with negative impacts than exceptionists (low relativism, low idealism).

The study of the influence of ethical philosophy in the context of moral judgment on tax evasion is very limited. Recent research that discusses the influence of ethical philosophy is [58]. They explain that idealism is negatively related to tax avoidance that comes from self-interest, while relativism is positively related to that attitude. Idealism also deals positively with attitudes to tax avoidance stemming from concerns about the fairness of the tax system. Another research was conducted by [9] in the context of consumer tax 
evasion. They find that idealism is a factor that can predict moral recognition significantly, whereas relativism is not.

H1a: Idealism negatively affects ethical perceptions of tax evasion

H1b: Relativism negatively affects ethical perceptions of tax evasion

\section{Religiosity dan Ethical Perception of Tax Evasion}

There are two views on religiosity, namely religious affiliation and religious commitment. [26] describes religious affiliation as a person's selfassociation with certain religions, such as Islam, Buddhism, and Christianity, whereas religious commitment is defined as the level of a person adheres to religious values, beliefs, and practices and uses them in daily life. [23] explain five dimensions that make up religiosity: intellectual, ideological, private practice, public practice, and religious experience.

Religiosity causes very little variability in moral reasoning which means those variables have no direct effect [3]. [8] also finds an insignificant influence between religiosity and moral reasoning. Another study finds religiosity has a negative relationship with an individual's moral development [1]. Research on the influence of religious commitment on perceptions of tax evasion shows different results. Studies conducted by [4] measures five items in variable religiosity, namely attendance in religious activities other than marriage and death, religious nature within, belief in God, the importance of God in life, and the frequency of prayer. The studies find that attendance in religious activities and religious traits had significant links to tax evasion perceptions in Christian and Islamic respondent groups; the importance of God in life is significant in Christian, Islamic, and Bahai groups; belief in God relates only significantly to the Christian group. The five items are not significant in Hindu and Jewish groups.

[60] in a study conducted in the United States finds a positive relationship between religiosity and tax morale. He finds that a single unit increase in the scale of religiosity would increase the number of individuals stating that tax evasion cannot be justified. In addition to religiosity, the number of visits to the Church also shows a positive relationship with tax morale. Research in the Czech Republic found that attendance in the Church had a significant positive effect on tax morale [59]. The effect is also strong and remains after control over age, gender, education, income, marital status, employment status, and occupational type.

$\mathrm{H} 2$ : Religiosity negatively affects ethical perceptions of tax evasion

\section{Tax Knowledge and Ethical Perception of Tax Evasion}

The relevant knowledge to understand moral events in tax is tax knowledge. [12] argues that tax knowledge refers to fiscal knowledge, knowledge of avoidance opportunities, public education, or knowledge of tax law. [6] defines tax knowledge as a level of taxpayer awareness or sensitivity to tax laws. Tax knowledge also refers to the process of taxpayers being aware of tax law and other taxrelated information.

[55] finds certain knowledge has a role in the development of moral judgment. Everyone may study a different subject. One might learn about history; others might learn how to solve problems from a moral point of view. [55] also explains that although a person takes a moral education, it does not necessarily improve judgment in moral judgment. [7] which focuses on general tax knowledge, found significant influence between tax knowledge and tax evasion. From the respondents who were students in Austria, [7] finds students hardly agree with tax evasion. This indicates tax knowledge negatively affects the perception of tax evasion action. Different results were found by [52]. The research was conducted in West Java, Indonesia, and finds that there is no significant impact of tax knowledge toward how they perceived tax evasion.

H3: Tax knowledge negatively affects ethical perceptions of tax evasion

\section{Education Level and Ethical Perception of Tax Evasion}

[55] explains that one of the most powerful and consistent factors influencing the moral development of judgment is formal education. Changes can occur due to dictated learning, stimulation of the self-discovery process, or enrichment of information. This can increase stimulation in understanding information or problems.

[27] finds that there is a link between education levels and views on tax evasion. In the questionnaire, [27] uses four reasons to justify tax evasion as an ethical act, namely an unfair tax system, taxes used inefficiently, taxes used to fund activities that respondents morally disapproved of, and high tax rates. Studies find that individuals with higher levels of education were more likely to oppose tax evasion. With their knowledge, they are considered to be able to understand tax evasion's negative impact on the social and economic. Besides that, he finds that education level has no impact on self-interest tax evasion.

[44] in their research that was conducted in Estonia showed the same result. The study is conducted on undergraduate, postgraduate, faculty, and practitioners in the field of business. The survey is conducted by providing 18 statements on reasons that could justify tax evasion as ethical. Of 
the 300 respondents, it is found that teachers and practitioners are the most opposed group to tax evasion, while undergraduate students were the least opposed to tax evasion.

A study conducted in Mexico finds different things [47]. The research is conducted on 401 students (both undergraduate and postgraduate) and teachers in business and engineering, as well as non-student groups. With the same questionnaire as [44], among the four groups, he finds that the one that opposed tax evasion the most is the nonstudent group.

H4: Education levels negatively affect ethical perceptions of tax evasion

\section{Ethical Perception of Tax Evasion and Tax Compliance}

According to [2], [36], [43], there are four views on the ethical perception of tax evasion. First, tax evasion is unethical because the citizen has debt to the state. Second, tax evasion is ethical because the state is not legitimate, it does not have the authority to make citizens give anything away. Third, tax evasion is sometimes ethical when the government cannot provide public goods. Fourth, there are moral obligations to do tax evasion when the state regime is oppressive or tyrannical. Those various perceptions toward tax evasion are found to have a direct impact on tax compliance [5], [24].

According to [29], tax compliance represents the willingness of taxpayers to pay taxes. Taxpayer compliance behavior can be due to the voluntary nature of the taxpayer or due to the enforcement of the government. Other research on ethics and tax compliance issues conducted by [53] finds that tax compliance would be higher when taxpayers are confident that tax evasion is unethical. [10] explained that ethical beliefs can be one of the means of understanding and improving tax compliance, especially for taxpayers with low moral development. They also find that when taxpayers have a strong moral belief that tax evasion is an unethical act, they have a higher level of compliance.

H5: Ethical perception of tax evasion negatively affects voluntary tax compliance

The variable relationships in this study are described as follows.

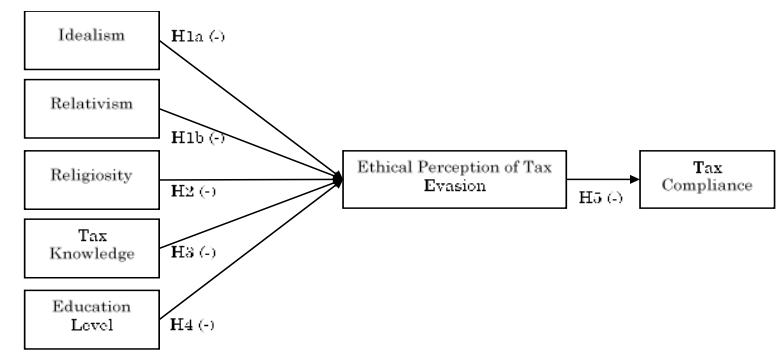

Figure 1. Variable Relationship

\section{RESEARCH METHODS}

This research is quantitative and uses primary data obtained from surveys. The survey was done in September 2020. Both individual taxpayer and non-taxpayer are selected to be survey respondents. The convenience sampling method is used to choose respondents. This method makes it easy for researchers to select the closest sample and are willing to fill out the survey. Convenience sampling was chosen due to limited time and costs. However, the results of this study cannot represent the population.

The survey is conducted through an online survey by giving a questionnaire to the target sample then filled out independently by the respondent. Before the data retrieval, the pilot test was conducted on 30 respondents to see if there were items that were not understood by the respondent. After checking the response, there are three multiple responses, so the total response analyzed is 291 of 294 responses. The respondent's profile is described in Table 1.

Table 1. Characteristics of Respondents

\begin{tabular}{lr}
\hline Gender & \\
\hline Male & 110 \\
Female & 181 \\
Total & 291 \\
\hline Age & 218 \\
\hline 18-27 & 40 \\
$28-37$ & 25 \\
$38-47$ & 8 \\
$48-58$ & 291 \\
Total & \\
\hline Religion & 7 \\
Buddha & 82 \\
Hindu & 173 \\
Islam & 14 \\
Catholic & 15 \\
Christian & 291 \\
Total & 2 \\
\hline Education Level & 51 \\
Senior High School & 175 \\
Diploma & 59 \\
Bachelor & 4 \\
Master & 291 \\
Doctoral & 146 \\
Total & 16 \\
\hline Occupation & 31 \\
\hline Student & 92 \\
Fresh Graduate & 132 \\
Lecturer & 159 \\
Professional & 291 \\
Business owner & \\
Total & \\
Tax Identification Number (TIN) & \\
\hline No TIN & \\
Have TIN & \\
Total & \\
\hline & \\
\hline
\end{tabular}




\section{Measures of Variables}

\section{Ethical Philosophy}

Ethical philosophy is measured by the Ethical Position Questionnaire (EPQ) developed by [16]. Of the twenty question items, only eight are used and have been translated into Bahasa Indonesia. This item has been used in several previous studies [9], [62]. The answer to EPQ items is measured on 5scales Likert.

\section{Religiosity}

Religiosity is measured using the Centrality of Religiosity Scale 7 (CRSi-7) by [23] which has been translated into Bahasa Indonesia. CRSi-7 is chosen because it has been modified so that it can be applied universally, not specifically to certain religious groups. CRSi-7 also shows high internal consistency with a Cronbach's Alpha value of 0.84 [23]. Based on the pilot test results, adjustments are made to the third and fourth items to make it easier for respondents to choose the answers.

\section{Tax Knowledge}

Tax Knowledge is measured by ten questions with multiple choices regarding knowledge of tax law. Question from [28] and adapted to the context of Indonesian tax law. Measurement is done by summing the value on each question, if respondents answer correctly, they get 1 . If they are wrong or answer 'does not know', they get 0 . The score is then summed, the range value is $0-10$. The final score obtained by each respondent is used as one indicator that reflects the tax knowledge variable.

\section{Ethical Perception of Tax Evasion}

Ethical perception of tax evasion measured using survey items compiled by [40] and has been translated into Bahasa Indonesia. From 18 items, only 17 were used. One item that is not used as a statement is "Tax evasion is ethical if I am a Jew living in Nazi Germany". In addition to being considered less relevant in the Indonesian context, the item is not used because there is a possibility that the respondent did not understand the conditions described in the statement. Survey answers are compiled using a 5-point Likert scale. The higher the score obtained indicates that the individual rates tax evasion as an ethical action.

\section{Voluntary Tax Compliance}

In this study, voluntary tax compliance represents the willingness of taxpayers to pay taxes without external enforcement. This variable is measured with questions compiled by [29]. The answers are in a 5-point Likert scale.

\section{Data Analysis}

Data are analyzed with Partial Least Square Structural Equation Modelling (PLS-SEM). PLSSEM is an SEM with a causal-predictive approach that emphasizes predictions in statistical estimation models whose structure is designed to explain causality relationships [21]. PLS-SEM is also appropriately used in research that tests predictive theoretical frameworks, has complex model structures with many constructs, as well as a small population [20]. In this study, the data is processed with the WarpPLS version 7.0, with the Bootstrapping resampling method. After building SEM-PLS Model based on Figure 1, we measure both the measurement and structural model. There will be some adjustment of the indicators if it does not meet the criteria. If there is any deletion of indicator(s), the model will be adjusted and then processed to hypothetical testing. Data analysis will be explained more in the next section.

\section{RESULTS AND DISCUSSION}

Before presenting the results, both measurement and structural model must be assessed with several procedures. The assessment is shown below.

\section{Measurement Model: Reflective Model Assess- ment}

The first step in testing reflective models is to see the loading factor value. [20] recommend loading values above 0.708. Deleting items may affect the content validity, therefore items with loading values between 0.4 and 0.7 are still tolerated [18]. These criteria do not apply to formative indicators. The testing of formative indicators will be explained in the next section. Table 12 shows the loading value of each indicator. All reflective indicators meet the loading value criteria $>0.5$ (Idealsm, Relativ, TaxKnow, EduLvl, EPTE, dan VTC). Religiosity is the formative indicator, so the loading value is ignored.

The second step is composite reliability assessment. Composite reliability or often referred to as internal consistency is one of the indicators to measure the reliability of a construct/variable [20]. A high value indicates a high level of reliability. The good composite reliability value is in the range of $0.70-0.90$. In exploration research value $0.60-$ 0.70 is still received [19]. [20] noted that composite reliability of more than 0.95 indicates the presence of recurring or redundant items. However, if no 
redundancy is found, a composite reliability value $>0.95$ is acceptable [19]. Table 3 shows latent variables of idealism, relativism, religiosity, voluntary tax compliance has composite reliability values of $>0.60$ and $<0.90$, while latent variables tax knowledge and EPTE have composite reliability values of $>0.950$.

Next, convergent validity testing is performed by looking at AVE (Average Variance Extracted), at least 0.5 for reflective latent variables [34]. All reflective latent variables (Idealsm, Relativ, Rligious, EPTE, and VTC) have an AVE value of $>0.5$.

The last step is the discriminant validity test. The discriminant validity is tested with the Fornell-Larcker criteria table. The root squared AVE latent variable should be greater than the correlation with other latent variables [20].

\section{Measurement Model: Formative Model Assess- ment}

To test formative latent variables in the measurement model, we look at the Variance Inflation Factor (VIF) value for each indicator. It is accepted if VIF $<2,5$, which indicating the absence of redundancy on each indicator [30]. [30] also recommends $p$-value $>0.05$. Indicators can be eliminated if they do not meet those criteria. In this model, the formative variable is religiosity. Religiosity is measured by seven formative indicators using CRSi7 compiled by [23]. Based on Table 6, the Relig5 (meditation frequency) indicator on the latent variable religiosity has a VIF value of $<2.5$ but is not significant ( $p$-value $>0.05$ ), so it is eliminated.

\section{Structural Model Assessment}

Figure 2 shows the structural model after adjustments to the religiosity indicator. Structural model testing is described in the following sections.

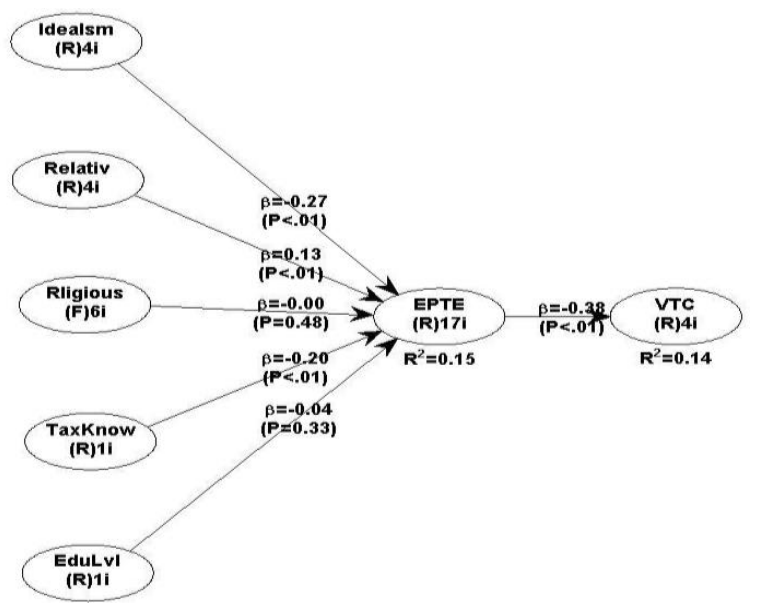

Figure 2. Structural Model

Collinearity testing needs to be done to ensure there is no bias in regression results [20]. A collinearity issue in the predictor variable occurs if the VIF value is more than 5 .

Table 2. Composite Reliability

\begin{tabular}{lccccccc}
\hline & Idealsm & Relativ & Rligious & TaxKnow & EduLvl & EPTE & VTC \\
\hline Composite Reliability & 0.866 & 0.837 & 0.720 & 1.000 & 1.000 & 0.954 & 0.833 \\
\hline
\end{tabular}

Table 3. AVE

\begin{tabular}{lllllll}
\hline Idealsm & Relativ & Rligious & TaxKnow & EduLvl & EPTE & VTC \\
\hline 0.623 & 0.564 & 0.304 & 1.000 & 1.000 & 0.550 & 0.555 \\
\hline
\end{tabular}

*Rligious is a formative variable, therefore the AVE value is ignored

Table 4. Fornell-Larcker Criterion

\begin{tabular}{lccccccc}
\hline & Idealsm & Relativ & Rligious & TaxKnow & EduLvl & EPTE & VTC \\
\hline Idealsm & $\mathbf{0 . 7 8 9}$ & 0.058 & 0.148 & 0.030 & 0.194 & -0.216 & 0.382 \\
Relativ & 0.058 & $\mathbf{0 . 7 5 1}$ & 0.023 & -0.004 & -0.200 & 0.142 & 0.032 \\
Rligious & 0.148 & 0.023 & $\mathbf{0 . 5 5 1}$ & 0.071 & 0.172 & -0.067 & 0.124 \\
TaxKnow & 0.030 & -0.004 & 0.071 & $\mathbf{1 . 0 0 0}$ & -0.072 & -0.186 & -0.024 \\
EduLvl & 0.194 & -0.200 & 0.172 & -0.072 & $\mathbf{1 . 0 0 0}$ & -0.079 & -0.315 \\
EPTE & -0.216 & 0.142 & -0.067 & -0.186 & -0.079 & $\mathbf{0 . 7 4 2}$ & 0.065 \\
VTC & 0.382 & 0.032 & 0.124 & -0.024 & -0.315 & 0.065 & $\mathbf{0 . 7 4 5}$ \\
\hline
\end{tabular}

Table 5. Indicator Weight, VIF, dan WLS

\begin{tabular}{|c|c|c|c|c|c|c|c|c|c|}
\hline & Idealsm & Relativ & Rligious & Tax Know & EPTE & Type & P-Value & VIF & WLS \\
\hline Relig1 & 0.000 & 0.000 & (0.188) & 0.000 & 0.000 & Formative & 0.003 & 1.080 & 1 \\
\hline Relig2 & 0.000 & 0.000 & $(0.323)$ & 0.000 & 0.000 & Formative & $<0.001$ & 1.579 & 1 \\
\hline Relig3 & 0.000 & 0.000 & $(0.215)$ & 0.000 & 0.000 & Formative & 0.001 & 1.128 & 1 \\
\hline Relig4 & 0.000 & 0.000 & $(0.286)$ & 0.000 & 0.000 & Formative & $<0.001$ & 1.244 & 1 \\
\hline Relig5 & 0.000 & 0.000 & $(0.033)$ & 0.000 & 0.000 & Formative & 0.354 & 1.181 & 1 \\
\hline Relig6 & 0.000 & 0.000 & $(0.372)$ & 0.000 & 0.000 & Formative & $<0.001$ & 1.712 & 1 \\
\hline Relig7 & 0.000 & 0.000 & $(0.251)$ & 0.000 & 0.000 & Formative & $<0.001$ & 1.231 & 1 \\
\hline
\end{tabular}


Table 6. VIF

\begin{tabular}{lllllll}
\hline Idealism & Relativ & Rligious & TaxKnow & EduLvl & EPTE & VTC \\
\hline 1.116 & 1.068 & 1.057 & 1.049 & 1.115 & 1.116 & 1.279 \\
\hline
\end{tabular}

Table 7. $\mathrm{R}^{2}$ Value

\begin{tabular}{|c|c|c|c|c|c|c|}
\hline Idealsm & Relativ & Rligiou & TaxKnow & EduLvl & EPTE & VTC \\
\hline & & & & & 0.147 & 0.144 \\
\hline
\end{tabular}

Table 8. $Q^{2}$ Value

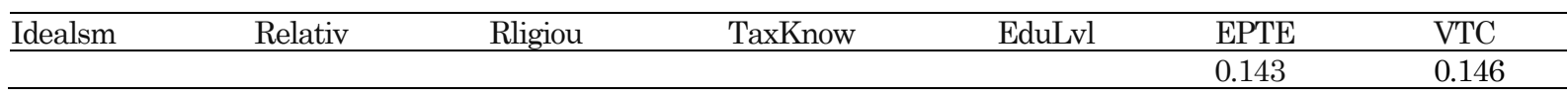

Table 9. Path Coefficient and P-value

\begin{tabular}{ccccccc}
\hline & $\begin{array}{c}\text { Idealsm } \\
(\mathrm{H} 1 \mathrm{a})\end{array}$ & $\begin{array}{c}\text { Relativ } \\
(\mathrm{H} 1 \mathrm{~b})\end{array}$ & $\begin{array}{c}\text { Rligiou } \\
(\mathrm{H} 2)\end{array}$ & $\begin{array}{c}\text { TaxKnow } \\
(\mathrm{H} 3)\end{array}$ & $\begin{array}{c}\text { EduLvl } \\
(\mathrm{H} 4)\end{array}$ & EPTE \\
\hline EPTE & $-0.271^{*}$ & $0.130^{*}$ & $-0.005^{* *}$ & $-0.199^{*}$ & $-0.040^{* *}$ & $-0.379^{*}$ \\
VTC & & & & & & \\
\hline
\end{tabular}

*p-value $<0.01$

$* *$ p-value $>0.05$

Table 10. T-ratios dan Confidence Interval

\begin{tabular}{lcccc}
\hline \multicolumn{1}{c}{ Construct } & $\begin{array}{c}\text { Critical } \\
\text { Tratios }\end{array}$ & T-ratios & Confidence Interval & Description \\
\hline Idealsm $>$ EPTE & 1.645 & -4.172 & $(0.398)-(0.144)$ & Supported \\
Relativ $>$ EPTE & 1.645 & 2.356 & $0.022-0.238$ & Supported \\
Rligious $>$ EPTE & 1.645 & -0.058 & $(0.172)-0.162$ & Not supported \\
TaxKnow $>$ EPTE & 1.645 & -4.137 & $(0.293)-(0.105)$ & Supported \\
EduLvl $>$ EPTE & 1.645 & -0.430 & $(0.223)-0.143$ & Not supported \\
EPTE $>$ VTC & 1.645 & -6.011 & $(0.503)-(0.256)$ & Supported \\
\hline
\end{tabular}

In the structural model, R2 or the determination coefficient is a value that reflects the ability level of an independent variable in describing dependent variables [49]. [20] explains that the value of $\mathrm{R} 2$ will differ in each discipline, so there is no definitive standard in classifying the value of R2. Human behavior cannot precisely predict, so the R2 value may be low. [63] explains that a value more than 0.1 was appropriately considered adequate.

The $\mathrm{Q}^{2}$ or Stone-Geisser $\mathrm{Q}^{2}$ coefficient is a non-parametric measurement used to assess predictive validity or relevance in each latent variable [33]. [20] recommend $\mathrm{Q}^{2}>0$ to see predictive validity.

\section{Hypothetical Testing}

Hypothetical testing is performed by looking at the coefficient path or coefficient of the path as well as the p-value of the coefficient of the path. The coefficient and $p$-value paths are not only able to reflect the strength of the relationship between variables, but also the strength of the tests performed [31], [32]. The path coefficient values are in the range of -1 to 1 . Values closest to -1 or 1 have the most powerful effect, while values close to 0 have the weakest effect [17].

Based on Table 10, the path coefficient for Idealism $>$ EPTE is -0.271 with a p-value $<0.01$, which means idealism has a significant negative influence on EPTE. The path coefficient for Relativism $>$ EPTE is 0.130 with a p-value $<0.01$, indicating relativism has a positive and significant effect on EPTE. Rligiou $>$ EPTE has a path coefficient of -0.004 with a p-value of 0.482 indicating there is no significant influence. The path coefficient value in TaxKnow $>$ EPTE is -0.201 with a p-value $<0.01$ indicating there is a significant negative influence. The coefficient of the path 0.033 and p-value of 0.332 indicates that there is no significant influence of EduLvl on EPTE. EPTE has a negative and significant effect on VTC with a path coefficient of -0.379 and a p-value $<0.01$.

Hypothesis testing can also be done by looking at T-ratios as well as confidence intervals. The hypothesis is accepted if the value is T-ratios > Critical T-ratios, and there is no value of 0 at the confidence interval. With a 0.95 confidence level, $\mathrm{H} 2$ and $\mathrm{H} 4$ are not supported.

Based on Table 10, the path coefficient for Idealism $>$ EPTE is -0.271 with a $p$-value $<0.01$, 
which means idealism has a significant negative influence on EPTE. The path coefficient for Relativism $>$ EPTE is 0.130 with a p-value $<0.01$, indicating relativism has a positive and significant effect on EPTE. Rligiou $>$ EPTE has a path coefficient of -0.004 with a p-value of 0.482 indicating there is no significant influence. The path coefficient value in TaxKnow $>$ EPTE is -0.201 with a p-value $<0.01$ indicating there is a significant negative influence. The coefficient of the path 0.033 and $p$-value of 0.332 indicates that there is no significant influence of EduLvl on EPTE. EPTE has a negative and significant effect on VTC with a path coefficient of -0.379 and a p-value $<0.01$.

Hypothesis testing can also be done by looking at T-ratios as well as confidence intervals. The hypothesis is accepted if the value is T-ratios > Critical T-ratios, and there is no value of 0 at the confidence interval. With a 0.95 confidence level, $\mathrm{H} 2$ and $\mathrm{H} 4$ are not supported.

\section{Discussion}

This research aims to look at the influence of ethical philosophies (idealism and relativism), religiosity, tax knowledge, and education levels on ethical perceptions of tax evasion, as well as the influence of ethical perceptions of tax evasion on tax compliance. From the results, religiosity and education levels have no significant effect ( $p>0.05$ ), relativism and tax knowledge had a significant positive influence $(p<0.01)$, while idealism has a negative and significant effect $(p<0.01)$. Ethical perception is known to have a significant negative effect on voluntary tax compliance $(p<0.01)$. The discussion of each variable is explained below.

The results of this study show that idealism has a significant negative influence on the ethical perception of tax evasion. The influence is based on a path coefficient value of -0.273 . Negative values in the path coefficient mean that the higher idealism will lead to a decrease in ethical perception, meaning respondents with higher scores in idealism consider tax evasion is unethical. This is in line with previous research [9], [58]. As explained by [15], in the moral judgment process, idealists tend to judge a situation based on moral principles. People who are idealists are concerned with how a decision will impact others. They will try to avoid actions that harm others, they believed that positive consequences can be achieved with more appropriate action without harming others and moral guidelines. In the case of tax evasion, the respondents in this research may not have a clear understanding of how tax evasion could harm others, but they know that tax evasion is violating the law, therefore they perceived tax evasion as unethical.
Relativism is found to have a positive influence on ethical perceptions of tax evasion with a coefficient value of 0.130 . The positive path coefficient indicates that the higher score on relativism, the more individuals consider tax evasion to be an ethical action to take, and it is in line with previous research [58]. In moral judgment theory, individuals with relativism tend not to pay attention to the basic principles of morality [15]. In this study, it can be interpreted that relativists will tend to have the perception that tax evasion is ethical to be carried out based on certain situations even they know that tax evasion is unlawful. It is known that relativists tend to adopt self-interest tax evasion, but it may be different because people have their own moral believe [58]. The way they perceive tax evasion may change based on their situations or experiences. In a weak tax system environment, relativists may not have a self-interest tax evasion attitude, but they have a strong reason to adopt tax evasion because of the unfair or unjust tax system.

The data showed that religiosity did not affect ethical perceptions of tax evasion, with a path coefficient of -0.004 and a p-value of 0.482 . The path coefficient is relatively small, which reflects the effect of religiosity on ethical perceptions of tax evasion is very weak. Also, the value of p-value $>0.05$, so the influence of religiosity is insignificant. This finding is supporting previous research [3], [8], but it is in contrast with another [4], [27], [59]. Indonesia society is known to uphold religious value, and Pancasila as state constitution also reflect divine values [57]. Religiosity is known based on shared values, and religious people may have similar ways of judging moral situations because they may follow common ethical principles. However, religiosity only generates conformity to others' ideals rather than an open examination of one's values and beliefs [8]. That being the case, we cannot determine people's moral judgment only based on their religiosity. Religiosity has an intricate relationship with the moral judgment that results in numerous findings in each recent study [3]. The other factor that may cause an insignificant result is the lack of sample size. Further research with a more representative sample is needed.

There is a significant negative influence (Path Coefficient $=-0.231, p$-value $<0.01$ ) between tax knowledge and ethical perception of tax evasion. The negative effect means the higher the level of tax knowledge, the more the individual will consider tax evasion to be an unethical act. This finding in line with research conducted by [7]. In the theory of moral development, moral judgment does not increase because individuals obtain 
certain moral education or other education [55]. However, in tax evasion perceptions, knowledge of taxation is found to influence how individuals view tax evasion. People with higher tax knowledge have a better understanding of the tax system, tax rate, allowances, and other tax facilities. They may have more awareness on how tax contributes to state funds, but they realized the government may corrupt it. Yet, they recognized that tax evasion is violating the law. For this reason, they perceive tax evasion as an unethical act.

Data from this study shows that there is no significant influence between the level of education and the ethical perception of tax evasion. The results are different from previous research [27], [44], but supporting others [47]. Several studies that examine the relationship between education level and tax evasion perceptions found various results [47]. [55] mentions that in moral judgment, education level should be one of the strong and consistent factors. Individuals with a higher level of education will have more information and that will help individuals understand the problem, which further impacts moral judgment. A possible explanation for why this research found the insignificant effect is the sample characteristics. Respondents are coming from different backgrounds. Even if their educational level is high, they may have little information or knowledge on the tax system because their background is not related to tax.

The results find that there is a significant negative influence of ethical perceptions of tax evasion toward voluntary tax compliance (Path Coefficient $=-0.379$, $p$-value $<0.01$ ). This means individuals who consider tax evasion to be ethical have lower levels of voluntary compliance, and vice versa, if the individual considers that tax evasion is ethical to do, it has a higher level of voluntary compliance. This finding is in line with the previous studies [10]. The result is also in line with [53], which explains that moral behavior will go hand in hand with the moral judgment of the invaded individual. [53] explained that taxpayers with stronger ethical considerations have higher compliance because they feel that they must comply with the law.

As stated before, respondents in this research come from various backgrounds including students who are not taxpayers. To provide more relevant information about voluntary tax compliance, the data is then processed to see how the ethical perception of tax evasion affects the taxpayer group and non-taxpayers. The influence of ethical perceptions found to be stronger in taxpayer groups (see Table 14). For this reason, tax authorities could improve voluntary tax compliance by shaping taxpayers' perception of tax evasion. Even if the impact is lower in the non-taxpayer group, their perceptions still matter because we can see them as potential taxpayers.

We try to look at what reasons may justify tax evasion as an ethical act among the respondents. Table 13 shows the mean value of each statement, higher mean value indicating the stronger the reason is for justifying tax evasion. The three most widely chosen reasons are the unfair tax system (Mean=2. 69, $\mathrm{SD}=1.30$ ), wasted tax money (Mean=2. 65, $\mathrm{SD}=1$. 32), and corrupted taxes (Mean=2. 55, SD=1. 40). Those three reasons are similar to [37] who recently surveyed Balinese taxpayers and [22] who surveyed students and taxpayers in Surabaya. Those reasons also parallel with the answers to open questions that we added in our questionnaire. Most of the respondents are criticizing Indonesia's tax system. Respondents criticized the unfair Indonesian tax system. Respondents think that the tax authorities have not been able to provide transparency on the tax revenues. Respondents also stated that there were still many cases of corruption, causing a low trust and sense of injustice for those who are obedient to tax law. Previous research already found that unfair tax systems, transparency, justice, corruption, and trust to tax authorities could also impact tax compliance [14], [38], [39], [51], [64]. The three weakest reasons to justify tax evasion as an ethical act are the wise use of taxes (Mean=1. 77, SD=1. 07), collected tax used for beneficial projects (Mean=1.81, $\mathrm{SD}=1.05$ ), and tax evasion is done by everyone (Mean=1.81, SD=1.04). From those answers, we can interpret that respondents relatively have a low self-interest intention to do tax evasion.

\section{CONCLUSION}

From the results of the study, it can be concluded that ethical philosophy and tax knowledge have a significant influence on the ethical perception of tax evasion. Religiosity and education levels do not influence ethical perceptions of tax evasion. Ethical perceptions are found to significantly affect voluntary tax compliance.

Those results can help understand the behavior of individuals related to tax evasion in Indonesia, especially from a non-economic point of view. As ethical philosophy is a personal characteristic that may hard to change, government especially tax authorities can focus on improving tax knowledge to shape people's perceptions toward tax evasion. The government can include basic tax knowledge as a subject in school or college, or through social media to reach more audiences. As the most reasons for justifying tax 
evasion are coming from external factors, the government could improve the tax system, government spending, and impede corruption to prevent people's intention to evade tax. Those strategies could help to form a better perception which would influence voluntary compliance.

This study is inseparable from some limitations. First, a small sample in this research, which is selected with convenience sampling method, could not represent the overall population, so further research with a more adequate and representative sample is needed. Second, the measurement of tax knowledge needs to be improved. Variables with one indicator are unlikely to be able to describe variables properly, so it is necessary to develop a tax knowledge measuring tool. Third, in the model, tax evasion is the only predictor of voluntary tax compliance. Future research can build a more comprehensive model to explain voluntary compliance with other variables.

\section{REFERENCES}

[1] Ahmadi, V., Davoudi, I., Mardani, M., Ghazaei, M., \& ZareZadegan, B. (2013). The Relationships Among Moral Development, Religiosity and Religious Orientation in Students. Procedia - Social and Behavioral Sciences, 84, 674-678. doi:10.1016/j.sbspro. 2013.06.624.

[2] Alasfour, F., Samy, M., \& Bampton, R. (2016). The Determinants of Tax Morale and Tax Compliance: Evidence from Jordan. Advances in Taxation, 125-171. 10.1108/s1058-749720 160000023005.

[3] Baumsteiger, R., Chenneville, T., \& McGuire, J. F. (2013). The Roles of Religiosity and Spirituality in Moral Reasoning. Ethics and Behavior, 23(4), 266-277. doi:10.1080/10508422. 2013.782814.

[4] Benk, S., McGee, R. W., \& Yiizbafi, B. (2015). How religions affect attitudes toward ethics of tax evasion? A comparative and demographic analysis. Journal for the Study of Religions and Ideologies, 14(41), 202-223.

[5] Bobek, D. D., Hageman, A. M., \& Kelliher, C. F. (2013). Analyzing the Role of Social Norms in Tax Compliance Behavior. Journal of Business Ethics, 115(3), 451-468. doi:10.1007/ s10551-012-1390-7

[6] Bornman, M., \& Ramutumbu, P. (2019). A conceptual framework of tax knowledge. Meditari Accountancy Research, 27(6), 823839. doi:10.1108/MEDAR-09-2018-0379

[7] Cechovsky, N. (2018). The importance of tax knowledge for tax compliance: A study on the tax literacy of vocational business students.
European Conference on Educational Research (ECER), Vocational Education and Training Network (VETNET)(September), 113-121. doi:10.5281/zenodo.1319718

[8] Corcoran, R. P., O'Flaherty, J., Xie, C., \& Cheung, A. C. K. (2020). Conceptualizing and measuring social and emotional learning: A systematic review and meta-analysis of moral reasoning and academic achievement, religiosity, political orientation, personality. $E d u$ cational Research Review, 30, 100285-100285. doi:10.1016/j.edurev.2019.100285

[9] Culiberg, B., \& Bajde, D. (2014). Do You Need a Receipt? Exploring Consumer Participation in Consumption Tax Evasion as an Ethical Dilemma. Journal of Business Ethics, 124(2), 271-282. doi:10.1007/s10551-013-1870-4

[10] Daniel, D., \& Wong, B. (2008). Issues on compliance and ethics in taxation: what do we know? Journal of Financial Crime, 15(4), 369382. doi:10.1108/13590790810907218

[11] Dee Theng, T. (2012). [Ethical perception on tax evasion by professional in MalaysiaProQuest].

[12] Devos, K. (2016). A comparative study of compliant \& non-compliant individual taxpayers in Australia. Journal of Business and Policy Research, 2(2), 180-196.

[13] Dewanta, M. A., \& Machmuddah, Z. (2019). Gender, Religiosity, Love of Money, and Ethical Perception of Tax Evasion. Jurnal Dinamika Akuntansi dan Bisnis, 6(1), 71-84. doi:10.24815/jdab.v6i1.10990

[14] Faizal, S. M., Palil, M. R., Maelah, R., \& Ramli, R. (2017). Perception on justice, trust and tax compliance behavior in Malaysia. Kasetsart Journal of Social Sciences, 38(3), 226-232. doi:10.1016/j.kjss.2016.10.003

[15] Forsyth, D. (1981). Moral Judgment: The Influence of Ethical Ideology. Personality and Social Psychology Bulletin, 7(2), 218-223. doi:10.1177/014616728172006

[16] Forsyth, D. R. (1980). A Taxonomy of Ethical Ideologies. Journal of Personality and Social Psychology, 39(1), 175-184. doi:10.2307/5245 28

[17] Garson, G. D. (2016). Partial Least Squares: Regression and Structural Equation Models: Statistical Publishing Associates.

[18] Hair, J. F., Hult, G. T. M., Ringle, C., \& Sarstedt, M., A primer on partial least squares structural equation modeling (PLS-SEM), Sage publications., 2016.

[19] Hair, J. F., Hult, G. T. M., Ringle, C. M., \& Sarstedt, M., A Primer on Partial Least Squares Structural Equation Modeling, SAGE., 2017.

[20] Hair, J. F., Risher, J. J., Sarstedt, M., \& Ringle, C. M. (2019). When to use and how to 
report the results of PLS-SEM. Emerald Group Publishing Ltd, 31, 2-24.

[21] Hair, J. F., Sarstedt, M., Ringle, C. M., \& Mena, J. A. (2012). An assessment of the use of partial least squares structural equation modeling in marketing research. Journal of the Academy of Marketing Science, 40(3), 414433. doi:10.1007/ s11747-011-0261-6

[22] Handayani, N. (2020). Persepsi calon wajib pajak dan wajib pajak tentang etika penggelapan pajak di Surabaya. 22(2), 274-285.

[23] Huber, S., \& Huber, O. W. (2012). The Centrality of Religiosity Scale (CRS). Religions, 3(3), 710-724. doi:10.3390/rel3030710

[24] Hunt, N. C., \& Iyer, G. S. (2018). The effect of tax position and personal norms: An analysis of taxpayer compliance decisions using paper and software. Advances in Accounting, 41 (March), 1-6. doi:10.1016/j.adiac.2018.02.003

[25] Ismail, S., \& Ghazali, N. A. M. (2011). Ethical ideology and ethical judgments of accounting practitioners in Malaysia. Gadjah Mada International Journal of Business, 13(2), 107123. doi:10.22146/gamaijb.5486

[26] Jun, B. W., \& Yoon, S. M. (2018). Taxpayer's religiosity, religion, and the perceptions of tax equity: Case of south Korea. Religions, 9(11), 1-15. doi:10.3390/rel9110333

[27] Khalil, S. (2020). The influence of religiosity on tax evasion attitudes in Lebanon. Journal of International Accounting, Auditing and Taxation, 100335-100335. doi:10.1016/j.intaccaudtax.2020.100335

[28] Kirchler, E., Maciejovsky, B., \& Schneider, F. (2003). Everyday representations of tax avoidance, tax evasion, and tax flight: Do legal differences matter? Journal of Economic Psychology, 24(4), 535-553. doi:10.1016/S01674870(02)00164-2

[29] Kirchler, E., \& Wahl, I. (2010). Tax compliance inventory TAX-I: Designing an inventory for surveys of tax compliance. Journal of Economic Psychology, 31(3), 331346. doi:10.1016/ j.joep.2010.01.002

[30] Kock, N. (2014). Advanced Mediating Effects Tests, Multi-Group Analyses, and Measurement Model Assessments in PLS-Based SEM. International Journal of e-Collaboration, 10(1), 1-13. doi:10.4018/ijec.2014010101

[31] Kock, N. (2015). One-tailed or two-tailed P values in PLS-SEM? International Journal of e-Collaboration, 11(2), 1-7. doi:10.4018/ijec.201 5040101

[32] Kock, N. (2016). Hypothesis testing with confidence intervals and $\mathrm{P}$ values in PLSSEM. International Journal of e-Collaboration, 12(3), 1-6.
[33] Kock, N., \& Gaskins, L. (2014). The Mediating Role of Voice and Accountability in the Relationship Between Internet Diffusion and Government Corruption in Latin America and Sub-Saharan Africa. Information Technology for Development, 20(1), 23-43. doi:10.1080/ 02681102.2013.832129

[34] Kock, N., \& Lynn, G. S. (2012). Lateral collinearity and misleading results in variancebased SEM: An illustration and recommendations. Journal of the Association for Information Systems, 13(7), 546-580. doi:10.17705/ 1jais.00302

[35] Kohlberg, L. (1981). The philosophy of moral development moral stages and the idea of justice.

[36] Lau, T.-C., Choe, K.-L., \& Tan, L.-P. (2013). The Moderating Effect of Religiosity in the Relationship between Money Ethics and Tax Evasion. Asian Social Science, 9(11). doi:10. 5539/ass.v9n11P213

[37] Mahaputra, I. N. K. A., Rustiarini, N. W., Anggraini, N. P. N., \& Sudiartana, I. M. (2018). National Culture and Perceived Ethics of Tax Evasion: Case of Bali Province. Journal of Economics, Business and Accountancy Ventura, 21(1), 89-104. doi:10.14414/jebav.v21i1. 1118

[38] Mahasurya, I. G. N. A., \& Budiartha, I. K. (2020). Religiusitas, Persepsi Korupsi Pajak Pelayanan Fiskus dan Kepatuhan Wajib Pajak. E-Jurnal Akuntansi, 30(11), 27132713. doi:10.24843/eja.2020.v30.i11.p01

[39] Mangoting, Y., Tangkelobo, H., \& Sina, W. L. (2019). Taxpayer Compliance Model Based On Transparency, Ethics and Trust. Jurnal Akuntansi dan Bisnis, 19(1), 104-104. doi:10.20961/ jab.v19i1.399

[40] McGee, R. W., The Ethics of Tax Evasion: Perspectives in Theory and Practice (pp. 125132), Attitudes on the Ethics of Tax Evasion: A Survey of Philosophy Professors, Springer., New York, 2012. 10.1007/978-1-4614-1287-8

[41] McGee, R. W., The Ethics of Tax Evasion: Perspectives in Theory and Practice (pp. 201210), Christian Views on the Ethics of Tax Evasion, Springer., New York, 2012. 10.1007/ 978-1-4614-1287-8

[42] McGee, R. W., The Ethics of Tax Evasion: Perspectives in Theory and Practice (pp. 451457), Education Level and the Ethics of Tax Evasion, Springer., New York, 2012. 10.1007/ 978-1-4614-1287-8

[43] McGee, R. W., The Ethic of Tax Evasion (R. W. McGee Ed.), Springer., New York, 2012.

[44] McGee, R. W., Alver, J., \& Alver, L., The Ethics of Tax Evasion: Perspectives in Theory 
and Practice (pp. 285-299), Tax Evasion Opinion in Estonia, Springer., New York, 2012. 10.1007/ 978-1-4614-1287-8

[45] McGee, R. W., \& Jain, R. K., The Ethics of Tax Evasion: Perspectives in Theory and Practice (pp. 321-336), The Ethics of Tax Evasion: A Study of Indian Opinion, Springer., New York, 2012. 10.1007/978-1-4614-1287-8

[46] McGee, R. W., \& M'Zali, B., The Ethics of Tax Evasion: Perspectives in Theory and Practice (pp. 301-308), The Ethics of Tax Evasion: A Study of Haitian Op, Springer., New York, 2013. 10.1007/978-1-4614-1287-8

[47] McGee, R. W., Petrides, Y., \& Ross, A. M., The Ethics of Tax Evasion: Perspectives in Theory and Practice (pp. 387-403), Ethics and Tax Evasion: A Survey of Mexican Opinion, Springer., New York, 2012.

[48] McGee, R. W., \& Yoon, Y., Attitudes Toward Tax Evasion in Korea: A Study in Public Finance, (pp. 272-283), Elsevier Inc., 2014. 10.1016/B978-0-12-800982-6.00015-9

[49] Mooi, E., \& Sarstedt, M., A Concise Guide to Market Research: The Process, Data and Methods using IBM SPSS Statistics: Springer Heidelberg Dordrecht London., New York, 2011.

[50] Mujiyati, M., Rohmawati, F. R., \& Ririn, W. H. (2018). Determinan Persepsi Mengenai Etika Atas Penggelapan Pajak (Tax Evasion). Riset Akuntansi dan Keuangan Indonesia, 3(1), 1-12. doi:10.23917/reaksi.v3i1.5551

[51] Muslichah, M., \& Graha, V. S. (2018). The Effect of Tax Fairnesson Tax Compliance withTrust as an Intervening Variable. AFRE (Accounting and Financial Review), 1(2), 7885. doi:10.26905/afr.v1i2.2372

[52] Pratama, A. (2017). Machiavellianism, tax knowledge, and ethical perceptions of tax avoidance: Survey of undergraduate students in West Java, Indonesia. International Journal of Trade and Global Markets, 10(1), 83-90. doi:10.1504/IJTGM.2017.082370

[53] Reckers, P. M. J., Sanders, D. L., \& Roark, S. J. (1994). The Influence of Ethical Attitudes on Taxpayer Compliance. National Tax Association, 47(4), 825-836.

[54] Rest, J., Thoma, S., \& Edwards, L. (1997). Designing and validating a measure of moral judgment: Stage preference and stage consis tency approaches. Journal of Educational Psychology, 89(1), 5-28. doi:10.1037/0022-0663 89.1.5.

[55] Rest, J., \& Thoma, S. J. (1985). Relation of Moral Judgment Development to Formal Education. Developmental Psychology, 21(4), 709-714. doi:10.1037/0012-1649.21.4.709

[56] Ritsatos,T. (2014). Tax evasion and compliance; rom the neo classical paradigm to behavioural economics, a review, Emerald Group Publishing Ltd, 10, 244-262.

[57] Saragih, A. H., Dessy, D., \& Hendrawan, A. (2020). nalisis Pengaruh Religiusitas Terhadap Kepatuhan Pajak Wajib Pajak Orang Pribadi. JPAK: Jurnal Pendidikan Akuntansi dan Keuangan, 8(1), 1-14. doi:10.17509/jpak. v8i1.16810

[58] Sidani, Y. M., Ghanem, A. J., \& Rawwas, M. Y. A. (2014). When idealists evade taxes: The influence of personal moral philosophy on attitudes to tax evasion - A Lebanese study. Business Ethics, 23(2), 183-196. doi:10.1111/ beer.12046

[59] Strielkowski, W., \& Čábelková, I. (2015). Religion, culture, and tax evasion: Evidence from the Czech Republic. Religions, 6(2), 657669. doi:10.3390/rel6020657

[60] Torgler, B., Attitudes Toward Paying Taxes in USA: An Empirical Analysis, Springer., New York, 2012.

[61] Trivedi, V. U., Shehata, M., \& Lynn, B. (2003). Impact of Personal and Situational Factors on Taxpayer Compliance: An Experimental Analysis. Journal of Business Ethics, 47(3), 175197. doi:10.1023/A:1026294332606

[62] Valentine, S. R., \& Bateman, C. R. (2011). The Impact of Ethical Ideologies, Moral Intensity, and Social Context on Sales-Based Ethical Reasoning. Journal of Business Ethics, 102(1), 155-168. doi:10.1007/s10551-011-0807-z

[63] van Tonder, E., \& Petzer, D. J. (2018). The interrelationships between relationship marketing constructs and customer engagement dimensions. Service Industries Journal, 38(1314), 948-973. doi:10.1080/02642069.2018.1425 398

[64] Yasa, I. N. P., \& Martadinata, I. P. H. (2019). Taxpayer Compliance from the Perspective of Slippery Slope Theory: An Experimental Study. Jurnal Akuntansi dan Keuangan, 20(2), 53-53. doi:10.9744/jak.20.2.53-61. 


\section{APPENDIX}

Table 11. Tax Knowledge*

\begin{tabular}{|c|c|c|}
\hline Number & Questions & Answer \\
\hline 1 & The highest rate of personal income tax in Indonesia is currently $30 \%$ & a. True \\
\hline 2 & Businesses that do not obtain tax holiday facilities are the communication equipment industry & b. False \\
\hline 3 & The type of tax decentralized in 2009 is the Land and Buildings Tax & c. Do not know \\
\hline 4 & $\begin{array}{l}\text { One of the characteristics/principles of the implementation of VAT in Indonesia is the origin } \\
\text { principle }\end{array}$ & \\
\hline 5 & The corporate income tax rate in Indonesia in 2019 is $22.5 \%$ & \\
\hline 6 & The date of publication of a tax invoice does not include the mandatory element of a tax invoice & \\
\hline 7 & Tax period equals one calendar month or at least 2 calendar months & \\
\hline 8 & Associations are not subject to tax under the Income Tax Act. & \\
\hline 9 & Income from sharia-based businesses is not an object of tax & \\
\hline 10 & $\begin{array}{l}\text { One of the deductible costs in the calculation of corporate income tax is the personal expense of } \\
\text { shareholders }\end{array}$ & \\
\hline
\end{tabular}

Table 12. Indicator Loading

\begin{tabular}{|c|c|c|}
\hline Question & $\begin{array}{l}\text { Indicator } \\
\text { Name }\end{array}$ & $\begin{array}{l}\text { Indicator } \\
\text { Loading }\end{array}$ \\
\hline The existence of potential harm to others is always wrong, irrespective of the benefits to be gained & Idea1* & 0.600 \\
\hline One should never psychologically or physically harm another person & Idea $2^{*}$ & 0.865 \\
\hline $\begin{array}{l}\text { One should not perform an action that might in any way threaten the dignity and welfare of another } \\
\text { individual }\end{array}$ & Idea $3^{*}$ & 0.889 \\
\hline If an action could harm an innocent other, then it should not be done & Idea $4 *$ & 0.770 \\
\hline $\begin{array}{l}\text { Questions of what is ethical for everyone can never be resolved since what is moral or immoral is up to the } \\
\text { individual }\end{array}$ & Relat1* & 0.779 \\
\hline $\begin{array}{l}\text { Moral standards should be seen as being individualistic; what one person considers to be moral may be } \\
\text { judged to be immoral by another person }\end{array}$ & Relat2* & 0.806 \\
\hline Different types of moralities cannot be compared to 'rightness' & Relat3* & 0.758 \\
\hline What is ethical varies from one situation and society to another & Relat4* & 0.652 \\
\hline How often do you think about religious issues? & Relig1*** & 0.398 \\
\hline To what extent do you believe that God or something divide exists? & Relig2 $2^{* * *}$ & 0.688 \\
\hline Ho w often do you take part in religious services? & Relig3*** & 0.456 \\
\hline How often do you pray? & Relig4*** & 0.608 \\
\hline How often do you meditate? & Relig5**** & 0.069 \\
\hline $\begin{array}{l}\text { How often do you experience situations in which you feel that God or something divide intervenes in your } \\
\text { life? }\end{array}$ & Relig6 $6^{* * *}$ & 0.792 \\
\hline How often do you experience situations in which you have the feeling that you are in one with all? & Relig7*** & 0.533 \\
\hline (see Table 11) & TaxKno* & 1.000 \\
\hline What is your current education level? & EduLvl* & 1.000 \\
\hline Tax evasion is ethical if tax rates are too high & EPTE1* & 0.721 \\
\hline $\begin{array}{l}\text { Tax evasion is ethical even if tax rates are not too high because the government is not entitled to take as } \\
\text { much as it is taking from me }\end{array}$ & EPTE2* & 0.727 \\
\hline Tax evasion is ethical if the tax system is unfair & EPTE3* & 0.665 \\
\hline Tax evasion is ethical if a large portion of the money collected is wasted & EPTE4* & 0.693 \\
\hline Tax evasion is ethical even if most of the money collected is spent wisely & EPTE5* & 0.759 \\
\hline Tax evasion is ethical if a large portion of the money collected is spent on projects that I morally disapprove of & EPTE6* & 0.769 \\
\hline Tax evasion is ethical even if a large portion of the money collected is spent on worthy projects & EPTE7* & 0.708 \\
\hline Tax evasion is ethical if a large portion of the money collected is spent on projects that do not benefit me & EPTE8* & 0.845 \\
\hline Tax evasion is ethical even if a large portion of the money collected is spent on projects that do benefit me & EPTE9* & 0.774 \\
\hline Tax evasion is ethical if everyone is doing it & EPTE10* & 0.748 \\
\hline $\begin{array}{l}\text { Tax evasion is ethical if a significant portion of the money collected winds up in the pockets of corrupt } \\
\text { politicians or their families and friends }\end{array}$ & EPTE11* & 0.639 \\
\hline Tax evasion is ethical if the probability of getting caught is low & EPTE12* & 0.762 \\
\hline Tax evasion is ethical if some of the proceeds go to support a war that I consider to be unjust. & EPTE13* & 0.779 \\
\hline Tax evasion is ethical if I can't afford to pay & EPTE14* & 0.716 \\
\hline Tax evasion is ethical even if it means that if I pay less, others will have to pay more & EPTE15* & 0.817 \\
\hline $\begin{array}{l}\text { Tax evasion is ethical if the government discriminates against me because of my religion, race, or ethnic } \\
\text { background }\end{array}$ & EPTE16* & 0.697 \\
\hline Tax evasion is ethical if the government imprisons people for their political opinions & EPTE17* & 0.762 \\
\hline I pay my taxes as required by the regulations because I pay my taxes voluntarily & VTC1* & 0.774 \\
\hline $\begin{array}{l}\text { I pay my taxes as required by the regulations without spending a long time thinking about how I could } \\
\text { reduce them }\end{array}$ & VTC2* & 0.696 \\
\hline I pay my taxes as required by the regulations to support the state and other citizens & VTC3* & 0.758 \\
\hline I pay my taxes as required by the regulations even if tax audits did not exist & VTC4* & 0.748 \\
\hline
\end{tabular}

*p-value $<0.01,{ }^{* *}$ p-value $=0.002,{ }^{* * * *}$ Formative indicators, loading value is ignored

Idea=Idealism, Relativ=Relativism, Rligious=Religiosity, TaxKno=Tax Knowledge, EduLvl=Education Level, EPTE=Ethical Perception of Tax Evasion, VTC=Voluntary Tax Compliance 
Table 13. Mean of EPTE

\begin{tabular}{|c|c|c|}
\hline Statement & Mean & SD \\
\hline Tax evasion is ethical if tax rates are too high & 2,22 & 1,23 \\
\hline $\begin{array}{l}\text { Tax evasion is ethical even if tax rates are not too high because the government is not entitled to take as } \\
\text { much as it is taking from me }\end{array}$ & 1,96 & 1,12 \\
\hline Tax evasion is ethical if the tax system is unfair & 2,69 & 1,30 \\
\hline Tax evasion is ethical if a large portion of the money collected is wasted & 2,66 & 1,32 \\
\hline Tax evasion is ethical even if most of the money collected is spent wisely & 1,78 & 1,07 \\
\hline $\begin{array}{l}\text { Tax evasion is ethical if a large portion of the money collected is spent on projects that I morally } \\
\text { disapprove of }\end{array}$ & 2,12 & 1,07 \\
\hline Tax evasion is ethical even if a large portion of the money collected is spent on worthy projects & 1,83 & 1,09 \\
\hline Tax evasion is ethical if a large portion of the money collected is spent on projects that do not benefit me & 1,95 & 1,06 \\
\hline Tax evasion is ethical even if a large portion of the money collected is spent on projects that do benefit me & 1,81 & 1,05 \\
\hline Tax evasion is ethical if everyone is doing it & 1,81 & 1,04 \\
\hline $\begin{array}{l}\text { Tax evasion is ethical if a significant portion of the money collected winds up in the pockets of corrupt } \\
\text { politicians or their families and friends }\end{array}$ & 2,56 & 1,40 \\
\hline Tax evasion is ethical if the probability of getting caught is low & 1,87 & 1,08 \\
\hline Tax evasion is ethical if some of the proceeds go to support a war that I consider to be unjust. & 2,32 & 1,24 \\
\hline Tax evasion is ethical if I can't afford to pay & 2,29 & 1,24 \\
\hline Tax evasion is ethical even if it means that if I pay less, others will have to pay more & 1,98 & 1,03 \\
\hline $\begin{array}{l}\text { Tax evasion is ethical if the government discriminates against me because of my religion, race, or ethnic } \\
\text { background }\end{array}$ & 2,38 & 1,26 \\
\hline Tax evasion is ethical if the government imprisons people for their political opinions & 2,38 & 1,25 \\
\hline
\end{tabular}

Table 14. The Effect of EPTE toward VTC and Mean of VTC by TIN Status

\begin{tabular}{|c|c|c|c|}
\hline \multirow{2}{*}{ TIN Status } & \multirow{2}{*}{$\begin{array}{c}\text { Path Coefficient } \\
\text { (EPTE }>\text { VTC) }\end{array}$} & \multicolumn{2}{|c|}{ VTC } \\
\hline & & Mean & SD \\
\hline No TIN (Non-Taxpayer) & -0.355 & 4.25 & 0.81 \\
\hline Have TIN (Taxpayer) & -0.399 & 4.50 & 0.76 \\
\hline
\end{tabular}

